\title{
AN OVERVIEW OF PESTICIDE MANAGEMENT IN NEPAL
}

Parashu Ram Adhikari ${ }^{1}$

\begin{abstract}
Agriculture is a wider sector where 54\% people are engaged and one-third GDP contributed to the nation. Due to diverse climatic regions, farmers grow different types of agricultural commodities and presence of different pests reduces their production and thus need to apply pesticides. Pesticide Registration and Management Division under the Department of Agriculture is a legal authority to register as well as restrict or ban certain pesticides used in the agricultural sector in Nepal. The paper also emphasizes how Nepal has doing pesticide reduction for the pest management in agriculture considering the food safety, animal and human health and environment protection. And it also focuses on the legal aspects on pesticide management and status of registered, restricted and banned pesticides in the context of neighboring countries and addresses to fulfill the obligations of the international convention related to pesticides and industrial chemicals.
\end{abstract}

Key words: Agriculture, banned pesticides, pesticides, pests, pesticide management

\section{INTRODUCTION}

Nepal a land locked country where $54 \%$ population is engaged in agriculture and one-third GDP contributed to the nation (ADS, 2016; NPC, 2016). Nepal has a diverse climate- from sub-tropical to alpine climate, but a number of factors explain the weak growth performance of agriculture as compared to the neighboring countries. Variety, irrigation, use of chemical fertilizer, pesticide, and intercultural operations play an important role to increase the productivity of crops. About 15$25 \%$ food products are being lost annually in pre and post harvest activities caused by pests and if the loss is minimized, it can play a significant role in food security.

Certain industrial chemicals and pesticides used in human health and agriculture sector cause harmful effect on human health, wild lives and pollute environment when they are not handled properly. International organizations and national legislative measures play an important role for the management of industrial chemicals and pesticides.

\section{METHODOLOGY}

The study have done on the basis of reviewing of published reports, documents, articles and presentation by the government of Nepal and other international organizations working in the fiels of pesticide management.

\section{FINDINGS}

PESTICIDE management

Institutional arrangements for the enforcement of law

1 Senior Plant Protection Officer, Ministry of Agricultural Development, Singh Durbar, Kathmandu, Nepal Corresponding : parashu.adhikari@gmail.com 
Nepal imports pesticides from India, China and other countries and those pesticides are used for vector control, external parasites in animals and pest management in agriculture. For the better management of pesticides, country has prepared the Pesticide Act, 1991 and Pesticide Regulation, 1993 and enforced them from July 16, 1994.

The pesticides either in use, production, formulation, distribution or professional applicators, should be registered or regulated under the Pesticide Act and Pesticide Regulation of Nepal. Under the Act, there is provision of Pesticide Management Board. The board advises to the government in the formulation of a national policy regarding pesticides to maintain co-ordination between private and government in production and distribution of pesticides, regulate and control the quality of pesticides, and prepare standard of pesticides. Under the Board, technical, legal and pesticide disposal implementation sub-committees have been established. Pesticide Registration and Management Division (PRMD), under Plant Protection Directorate is responsible for pesticide registration, monitoring and management in central and 75 pesticide inspectors are responsible in district level (Pesticide regulation, 1993).

\section{Monitoring and supervision mechanism}

There is provision of Pesticide inspectors and district pesticide management committee in the Act for the management of pesticides in the districts. Act has given the legal authority to the pesticide inspectors for pesticide import and check the pesticide shop, go down and factories to monitor the quality and valid license.

\section{Requirements for pesticide registration}

At present, due to lack of pesticide quality checking laboratory facilities and experts, Nepal has to rely on foreign analysis result of pesticides. The pesticides are registered on the basis of trade name. Pesticide Registration and Management Division demands the following documents during the registration:

a. Summary of intended use pattern

b. A statement of the need to use in Nepal

c. Evidence that the product is registered overseas (copies of registration certificates, affidavits or approved labels)

d. Three copies of the original label of the product to import and sale

e. $\quad$ Report of EIA (Environmental Impact Assessment) for more than $10 \mathrm{mt}$

f. For research no attachments are necessary

Any persons, institutions, or companies can submit by attaching the required documents for the registration of pesticides, the board may make necessary inquiry during the process of registration and grant the retailer license.

\section{Notified pesticides}

According to the Pesticide Regulation Section 9, the government should publish the name of the registered pesticides in the Nepal Gazette after recommendation by the board. Those pesticides other than notified ones, are not to be imported, exported, produced, used and distributed (Pesticide Act, Section, 11). All the terms and conditions are specified in the license and should meet required minimum standard.

Registration situation 
The pesticide registration situation varies country wise in the world. Generally, pesticide is registered after evaluation of country specific risk analysis. Pesticide handling, disposal and management training is provided to the technicians and resellers. The registered pesticides and information related to pesticide management in Nepal is presented in Table 1 and 2, respectively.

Table 1: Pesticides registered in Nepal

\begin{tabular}{lcc}
\hline & Commonname & Trade name \\
\hline Insecticides & 51 & 1288 \\
Acaricides & 6 & 23 \\
Fungicides & 38 & 564 \\
Bactericides & 1 & 13 \\
Herbicides & 22 & 288 \\
Rodenticides & 2 & 29 \\
Molluscides & 1 & 2 \\
Biopestcides & 9 & 78 \\
Herbal & 3 & 4 \\
Total & 132 & 2289 \\
\hline
\end{tabular}

Source: PRMD, 2016

Table 2. Information related to pesticides management

\begin{tabular}{lc}
\hline Particular & Number \\
\hline Registered pesticides (trade name) & 2289 \\
Registered pesticides (common name) & 132 \\
Pesticide handling training for reseller & 11242 \\
Pesticide license & 9954 \\
Pesticide formulators & 6 \\
Pesticide applicators & 15 \\
Pesticide importer & 160 \\
\hline
\end{tabular}

Source: PRMD, 2016

\section{PESTICIDE IMPORT AND CONSUMPTION}

\section{Use of pesticides}

Pesticides are mainly used in vector control external parasites of animals and agriculture for pest control for pre- and post- harvest loss reduction. The total area covered by agriculture is 35912 square kilometer and use of pesticide amount depends upon the crops. Pesticides are used mainly in vegetables, tea, legumes, rice and maize. About $80 \%$ pesticides are used in vegetables. A recent study shows that the average pesticide used in Nepal is about $396 \mathrm{gm} / \mathrm{ha}$ (PPD, 2014), which was only $142 \mathrm{gm} /$ ha in 1995 (IUCN, 1995). 
Table 3: Cultivated area by different geographical regions

\begin{tabular}{llcccc}
\hline SN & $\begin{array}{c}\text { Geographical } \\
\text { region }\end{array}$ & \multicolumn{2}{c}{ Area of the country $\left.\mathbf{( k m}^{2}\right)$} & $\begin{array}{c}\text { Total cultivated area } \\
\text { of the country (\%) }\end{array}$ & $\begin{array}{c}\text { Percent of } \\
\text { cultivated area }\end{array}$ \\
\cline { 3 - 4 } & \multicolumn{1}{c}{ culal } & Cultivated & & \\
\hline 1. & Himalayan & 51313 & 1436 & 4.0 & 2.8 \\
2. & Hills & 61816 & 9337 & 26.0 & 15.0 \\
3. & Terai & 33851 & 25138 & 76.5 & 17.0 \\
\hline & Total & $\mathbf{1 4 7 1 8 1}$ & $\mathbf{3 5 9 1 2}$ & $\mathbf{1 0 0 . 0}$ & $\mathbf{2 4 . 0}$ \\
\hline
\end{tabular}

Source: MoAD, 2014

Table 4: Pesticide consumption by crops

\begin{tabular}{llccc}
\hline SN & Crops & $\begin{array}{c}\text { Total cultivated } \\
\text { area (ha) }\end{array}$ & $\begin{array}{c}\text { Total pesticide used } \\
\text { (a.i. kg) }\end{array}$ & $\begin{array}{c}\text { Pesticide quantity } \\
\text { (a.i.kg/ha) }\end{array}$ \\
\hline 1. & Cereals & 953.379 & 43.975 & 0.046125 \\
2. & Vegetables & 320.290 & 513.967 & 1.604693 \\
3. & Cash Crops & 69.266 & 12.921 & 0.186542 \\
4. & Pulses & 42.916 & 2.178 & 0.05075 \\
5. & Fruits & 66.880 & 1.952 & 0.029187 \\
\hline & Total & 1452.730 & 574.993 &
\end{tabular}

Source: PPD, 2015

\section{Pesticides used as WHO class}

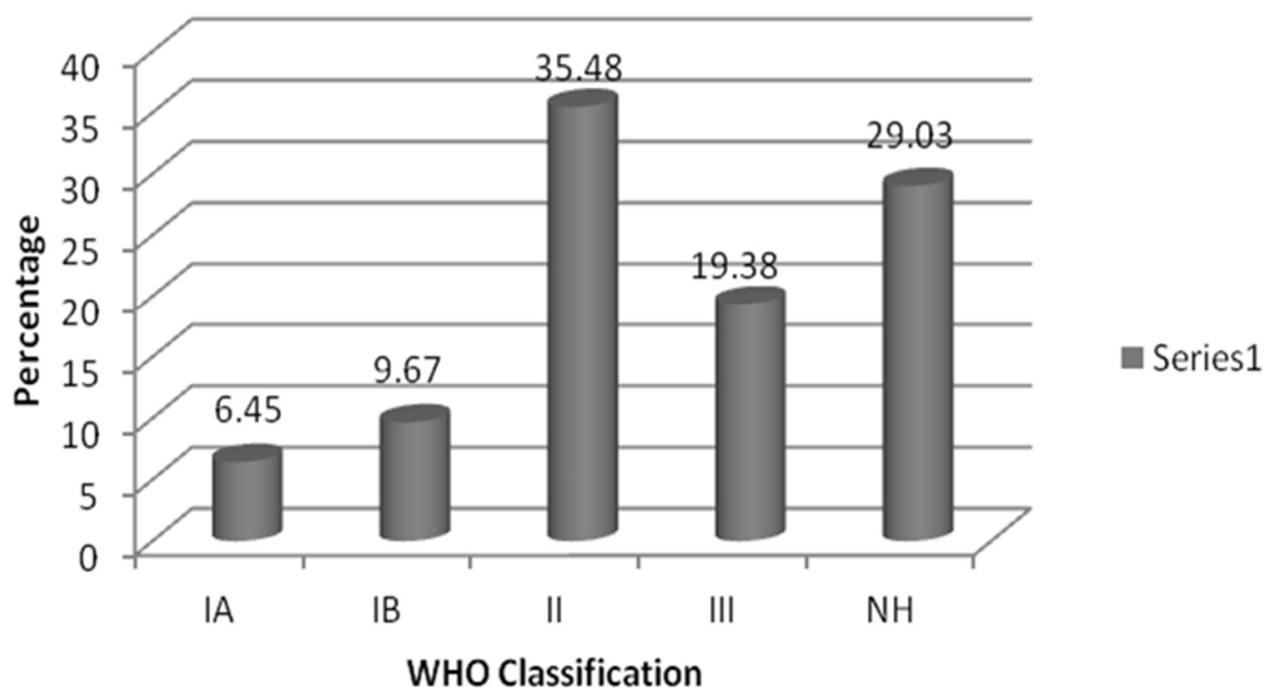

Figure 1. Pesticide used by WHO classification (Source: Sharma, 2014) 
According to WHO classification, Nepal has registered Ib, II, III and $\mathrm{U}$ pesticides, and try to reduce the register and use of highly hazardous (Ib) and moderately hazardous (II) pesticides by advocating the consequences of pesticides and promotion of IPM and use of bio-pesticides.

Table 5: Pesticide consumption in Nepal

\begin{tabular}{llccc}
\hline SN & \multicolumn{1}{c}{ Pesticides } & Total quantity $(\mathrm{mt})$ & $\begin{array}{c}\text { Total quantity a.i. } \\
(\mathrm{mt})\end{array}$ & Value ('000 US\$) \\
\hline 1. & Insecticide & 113.88 & 162.32 & 2855.56 \\
2. & Fungicide & 27.69 & 19.22 & 1315.29 \\
3. & Bactericide & 0.03 & 0.0031 & 8.96 \\
4. & Herbicide & 19.27 & 9.01 & 859.49 \\
5. & Rodenticide & 1.45 & 0.98 & 89.47 \\
6. & Bio-pesticide & 0.63 & 0.0071 & 34.84 \\
\hline & Total & $\mathbf{1 6 2 9 . 5 0}$ & $\mathbf{4 5 4 . 5}$ & $\mathbf{5 1 6 3 . 6 1}$ \\
\hline Source: PRMD, 2014 (1 US\$ = NRs 106.9) & & &
\end{tabular}

\section{Misuse/overuse of pesticides}

The proper use of pesticide give results increase in agriculture production and vector control while misuse effect on health and environment. Baker and Gyawali (1994) highlighted the misuse of pesticides in four thematic issues, viz. health effect, environment damage, yield reduction and financial expenses. Within in these issues, there are many such consequences in case of Nepal.

\section{GOVERNMENT STRATEGY}

Especially during the 1970s, pesticide use increased with the beginning of agricultural technology transformation in the farmers to increase production for food security. Cotton Development Committee, Agricultural Inputs Corporation, Government Agriculture farm and Research Stations, District Agriculture Development Offices and Frontline Extension Workers are the main promoters of pesticide in Nepal. Besides, sectorial plans, programs and activities also emphasized the promotion of pesticides.

In 1996, when brown planthopper (Nilapervata lugens) outbreak occurred in rice and caused an estimated loss of US\$212201. Then government of Nepal emphasized integrated pest management (IPM) strategy for the management of such pests by educating the farmers through farmer field school (FFS) in their own community. Nepal has been emphasizing the IPM from the beginning to date with the technical and financial support of FAO and some outputs are as follows:

- Technical Cooperation Project (FAO/TCP): 1997-1999

- Community IPM program : 2000

- National IPM Program -Phase I : 2003 - 2007

- National IPM Program -Phase II: 2008- 2013

Due to climate change, new and secondary pests have been increased (Mythimna seperata or Spodoptera mauritia), causing severe damage to crops, vegetables and fruits, giving birth to the climate field school in climate vulnerability communities.

The National Plant Quarantine Programme (NPQP) has developed 33 national standards harmonizing with ISPM, starting to build fumigation chamber (ISPM 15), pest database and beginning preliminary database of 20 tradable crops, pest risk analysis of some important crops, initial work on pest free areas (ISPM No. 4), and conducted training for plant health inspectors. 
The new Plant Protection Bill 2017 has been prepared harmonizing with IPPC guidelines, Protocols and the WTO/SPS Agreement and is in the process of discussion in parliament for approval.

\section{Community IPM}

Table 6: Participation in different programs

\begin{tabular}{llcl}
\hline SN & Training/workshop & No & Participants/Organization \\
\hline 1. & Strategy development, policy, and curriculum workshop & 3 & MOA, DOA, PPD, NARC, FAO \\
2. & Season long Rice IPM TOT officer level & 1 & 30 APPOS, 1 NARC, NGOs \\
3. & Vegetable IPM TOT & 1 & $30 \mathrm{GOs}$ and 4 NGOs officers \\
4. & Season long Rice IPM TOT (JT level) & 1 & $17 \mathrm{JT} /$ As (GO) and 17 JTs NGO \\
5. & Training on Participatory planning & 2 & 39 IPM trainers \\
6. & Training on Science by farmers & 2 & 36 IPM trainers \\
7. & Farmer TOT & 5 & 156 farmers \\
8. & Rice FFS by official trainer & 404 & 10100 farmers \\
9. & Vegetable FFS by official trainer & 23 & 575 farmers \\
10. & Farmer to farmer FFS & 246 & 6150 farmers \\
11. & Farmer Science & 14 & 350 farmers \\
\hline
\end{tabular}
Source: PPD, 2015

Table 7: IPM training

\begin{tabular}{llc}
\hline SN & Major activities & Numbers (Up to 2015) \\
\hline 1. & Officer level IPM ToF( Subject Matter Specialist) & 179 \\
2. & Non officer levels IPM ToF (JT/JTA) & 276 \\
3. & Farmers Facilitators & 882 \\
4. & Season Long IPM FFS & 4425 \\
5. & Yearlong IPM FFS & 196 \\
\hline
\end{tabular}

Source: PPD, 2015 \}

\section{Production and use of bio-pesticides}

Due to the negative effects of chemicals pesticide in crops, residue in foods, and environment pollution, use of bio-pesticides has been gradually increasing their use in vegetables at FFS conducted communities and started to register such eco-fiendly products. Farmers have started plant based bio-pesticides who learnt from the FFS and training. The amount of use of bio-pesticide is negligible as compared to chemical pesticides.

Table 8: Registered bio-pesticides

\begin{tabular}{clcc}
\hline SN & \multicolumn{1}{c}{ Bio-pesticide } & Trade name & Category \\
\hline 1. & Azadirachtin & 10 & Plant based \\
2. & Beauveria bassiana & 8 & Fungus \\
3. & Metarhizium anisopliae & 3 & Fungus \\
4. & NPV & 2 & Virus \\
5. & Pseudomonas fluorescene & 6 & Bacteria \\
6. & Trichoderma viride & 8 & Fungus
\end{tabular}


7. Trichoderma harzianum

8. Verticillium lecani

Total

42

Source: PRMD, 2014

Five community IPM Resource Centers were established in districts to support the IPM farmers and 21 farmers were trained on lab handling and bio-agent rearing. The products are used by the group members and sold as per need within the district. Such local measures used to control pests have been found effective and cheap.

\section{Disposal of obsolete pesticides}

Nepal was facing a problem for disposal of pesticide and even in 1990, about $150 \mathrm{mt}$ of obsolete pesticide were stored in different locations of Nepal, of which $114 \mathrm{mt}$ were disposed, including 16 $\mathrm{mt}$ reused, $23 \mathrm{mt}$ reformulated and $75 \mathrm{mt}$ disposed by land spreading and buried. Later in 2007, Nepal disposed $74.5151 \mathrm{mt}$ of date expired pesticides including POPs (33.668 mt) and 43 cylinders (50kg each cylinder) methyl bromide with the help of German government (MoEST, 2007).

\section{Establishment of RBPR analysis laboratory}

TheGovernment of Nepal is decided to establish the Rapid Bioassay of Pesticide Residue (RBPR) laboratory in Kalimati fruits and Vegetable Market to check the pesticide residue in vegetables before sell. The laboratory is established in 18 June, 2014 under the supervision of Plant Protection directorate. RBPR technology is developed by Taiwan Agriculture Research Institute in 1985 to check the residue of organophosphate and carbamates groups of pesticides and fungicides residue in certain level through Enzymatic reaction: AchE (Acetyl cholinesterase) Test to screen the residues of acetyl cholinesterase-inhibiting in fruits and vegetable.Test gives only inhibition percentage from which the result is withdrawn below $35 \%$ is edible, $35-45 \%$ need quarantine for few days and warning and more than $45 \%$ considered as not edible in toxicological sense. The RBPR/TARI program pack is recorded the AchE reaction and calculated the inhibition percentage through Spectrophotometer. The increasing absorbance for sample at $412 \mathrm{~nm}$ is recorded and compared to the insecticide free blank (normal) AchE reaction, and the inhibition percentage is calculated.

$$
\text { \%inhibition }=\frac{\text { Absorbance }(\text { normal })-\text { Absorbancechange }(\text { Sample })}{\text { Absorbancechange }(\text { normal })} \times 100
$$

We have got the following result of residue of pesticides in fruits and vegetables in Kalimati fruits and Vegetable Market in three year after establish the RBPR laboratory.

In 2014,out of 187 samples, the inhibition percentage of 155 samples $(82 \%)$ found below $35 \%$ (edible), 6 samples $(3 \%$ ) found in 35- $45 \%$ (quarantine) ie need to wait for some days to consume and rest 26 smaples (14\%)above $45 \%$ (non edible) to be dump.

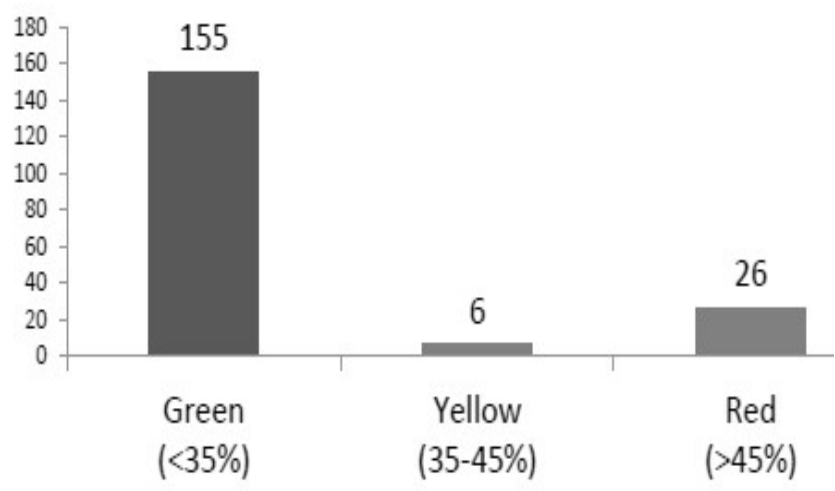

Source: PPD, 2016 


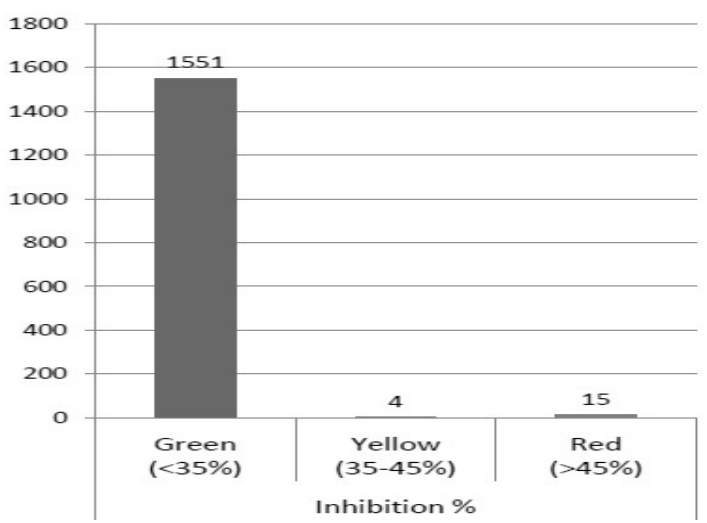

Source: PPD, 2016

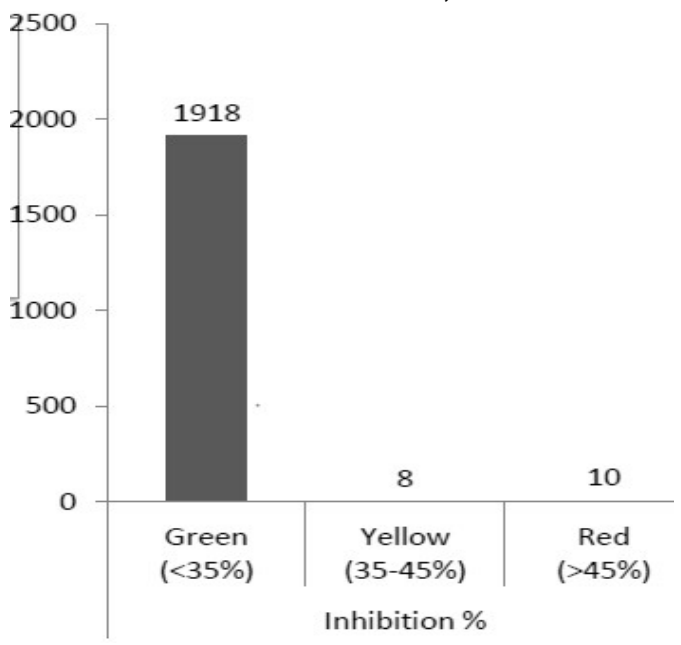

Source: PPD, 2016
In 2015, out of 1570 samples, the inhibition percentage of 1551 samples $(98.7 \%)$ found below $35 \%$ (edible), 4 samples $(0.2 \%)$ found in $35-45 \%$ (quarantine) ie need to wait for some days to consume and rest 15 samples (1\%) above $45 \%$ (non edible) to be dump.

In 2016, out of 1918 samples, the inhibition percentage of 1551 samples (99.1\%) found below 35\%(edible), 8 samples $(0.4 \%)$ found in $35-45 \%$ (quarantine) i.e. need to wait for some days to consume and rest 10 samples $(0.5 \%)$ above $45 \%$ (non edible) to be dump.

The three year analysis result showed that the farmers have increased the knowledge of waiting period pesticide or they used the safe level of pesticide in vegetables, fruits and potato. The region may be those marketing commodities which may have higher pesticide residue may be sold another market rather than the Kalimati.

We can draw the conclusion by the three year analysis report of RBPR laboratory Kalimati, farmers have aware the safe use of pesticide for market their products, District Agriculture Offices and Regional Training Centers also have conducted the safe use of pesticide and consciousness raised in the consumer level. So due to its positive impacts on the program, Government of Nepal have started to establish RBPR laboratory in Jhapa (Birtamod), Sarlahi (Nawalpur), Kaski (Pokhara), Rupandehi (Butwal), Banke (Nepalgunj), Kailali (Attaria).

\section{National action of the Rotterdam Convention}

Nepal is a party of Basel, Rotterdam and Stockholm Conventions and should fulfill the obligations. Ministry of Agricultural Development has Designated National Authority (DNA) of industrial chemicals and pesticides of Rotterdam Convention. The Government of Nepal has decided to band fifteen following pesticides and chemicals for their import, production and use. 
Table 9: Banned pesticide in Nepal

\begin{tabular}{llcllc}
\hline SN & Name of pesticide & Category on RC & SN & Name of pesticides & Category on RC \\
\hline 1. & Aldrin & Annex A & 9. & Organo mercury compound & \\
2. & BHC & POP & 10. Mirex & Annex B \\
3. & Chlordane & Annex A & 11. & Phosphamidon & SHPF \\
4. & DDT & Annex B & 12. & Toxaphene & Annex B \\
5. & Dieldrin & Annex A & 13. Methyle parathion & SHPF \\
6. & Endrin & Annex A & 14. Monochrotophos & \\
7. & Heptaclor & Annex A & 15. Endosulfan & \\
8. & Lindane & Annex B & & & \\
\hline
\end{tabular}

Source: PRMD, 2012, MoAD, 2015

The important source of information on pesticides in Asia and Pacific is pesticide database of Asia Pacific Plant Protection Convention (APPPC) website, which contains among others information on the list of registered pesticide and the list of banned and restricted pesticide in Asia. According to the recent report developed by the Asia Pacific Plant Protection Convention, the statuses of banned pesticides in the region are as follows:

Table 10:Prohibited and banned pesticides in listed countries of Asia

\begin{tabular}{cc}
\hline Countries & Number of prohibited and banned pesticides \\
\hline China & 58 \\
India & 72 \\
Indonesia & 101 (Including pesticides banned in rice) \\
Laos & 55 \\
Malaysia & 45 \\
Nepal & 15 \\
Srilanka & 40 \\
Thailand & 40 \\
Vietnam & 203 (including industrial chemicals) \\
\hline
\end{tabular}

Source: Paper presented on "Sub -Regional Workshp for the Designated National Authorities on the Rottardam Convention focusing on Increasing Notification "at Surabaya, Indonesia on March 13-17, 2017 and organized by FAO/APPPC, Rottardam Convention Secretoriate and Ministry of Agriculture, Indonesia

Obligations to international plant protection convention

Members of International Plant Protection Convention have to submit reports on national obligations, viz. description of NPPO, legislation (phytosanitory requirements, restriction, 
prohibition), entry points, list of regulatory pests, pest reports (33 commodities), organizational arrangements of plant protection, rational for phytosanitary requirements, non-compliance, pest status, emergency actions. Organizational arrangements of plant protection, rational for phytosanitary requirements, non-compliance, and emergency actions. In this line, in 2005, a list of banana (Musa sapientum L.) diseases of regulated pests, in 2011, new insect in mango, red banded mango caterpillar (Deanolis sublimbalis), and in 2016, South American tomato leaf miner (Tuta osbsoluta) have been observed and reported to IPPC.

\subsection{Pesticide Association of Nepal}

Pesticide Association of Nepal (PAN) is an umbrella organization of pesticide professionals established in 1977 to integrate the Nepali firms, companies and individuals involved in the import, distribution and marketing of pesticides. The association specially focuses to aware on the safe use, handling and disposal of pesticides through training and mass communication and facilitates the licensing training for participants. This organization has been involving in most of pesticide activities conducted by the PRMD.

\section{NATIONAL CHALLENGES}

Most of the pesticides used in Nepal are imported from India and China. The government has not provided any subsidy in pesticides. The pesticide market has been taken over by whole sellers and retailers. More than $60 \%$ farmers are consulting the pesticide resellers for seeking advice to their problems while most of the resellers are non-technical persons, and so increase chances of misuse and improper handling of pesticide. Different kinds of national challenges on the national prospective are as follows:

- Landlocked country and porous border where pesticides can easily penetrate.

- Illegal entry of pesticides and distribution in local market.

- Pesticide whole sellers and retailers have not sufficient knowledge on agriculture and pesticide transport, storage, use and disposal.

- Due to open and porous border situation, there may be chances of movement of nonregistered and banned pesticides as well.

- Disposal problems of date expired pesticides.

- Lack of laboratory facility for identification and quality residue and analysis.

- Lack of knowledge of farmers about the pesticides handling, use and disposal.

- Resellers cannot supply standard bio-pesticides in sufficient quantity.

\section{WAY FORWARD}

Afer the development of high yielding new varieties of crops, vegetables, and fruits the use of pesticides have increased due to succeptability of disease and pests in those varieties.Off-season vegetable and year round production of other crops also increased the demand of pesticides. Pesticide Registrationand Management Division has doing for the registration, monitoring, banned of highly peaticides and resion of program in the management of pesticides with in the country. Some immediate and urgent actions to be taken in the field of pesticide managent are: 
- The new pesticide management bill in the parliament with appropriate decision might help to manage the pesticide in the new perspective.

- Highly hazardous pesticide (la) of WHO class are to be replaced by other alternatives and prohibit their registration in coming days.

- Mass campaign and advocacy is necessary on the safe production, safe selection, and safe use, personal safety during application, enough waiting period, and proper disposal of pesticides.

- Timely actions are required for the promotion of organic production, IPM technology, use of biochar, bio-pesticide, lures and pheromones for the pest management and reduction in pesticide residues.

- Good linkage and coordination is needed with relevant Regional and International organizations for technical and financial support in pests and pesticide management.

\section{REFERENCES}

1. ADS, 2016. Ministry of Agricultural Development, Singh Durbar, Kathmandu, Nepal.

2. Baker, S., and Gyawali, B.K. 1994. Promoting proper pesticide use in Nepal. Policy analysis in agriculture and related resource management research report 28. Ministry of Agriculture, and Winrock International, Kathmandu, Nepal.

3. Dahal, L. 1995. A study on pesticide pollution in Nepal. National Conservation Strategy Implementation Project, National Planning Commission, HMG Nepal, in collaboration with IUCN. Kathmandu, Nepal.

4. MoEST, 2007. Nepal National Implementation Plan for the Stockholm Convention on Persistent Organic Pollutants (POPs). Singh Durbar, Kathmandu, Nepal.

5. Ministry of Agricultural Development, 2014. Annual Report. Singh Durbar, Kathmandu, Nepal.

6. Pesticide Regulation.1993. Nepal Law Commission, Singh Durbar, Kathmandu, Nepal.

7. NPC, 2016. Fourteen Plan. Singh Durbar, Kathmandu, Nepal.

8. PRMD, 2014. Annual Report. Harihar Bhawan, lalitpur, Nepal.

9. PPD, 2014. Annual Report. Harihar Bhawan, Lalitpur, Nepal.

10. PPD, 2015. Annual Report. Harihar Bbhawan, Lalitpur, Nepal.

11. PPD, 2016. Annual Report. Harihar Bbhawan, Lalitpur, Nepal.

12. Sharma, D.R., 2014. Use of pesticides in agriculture. PhD Thesis. Institute of Agriculture and Animal Science, Tribhuvan University, Kathmandu, Nepal. 